\title{
ANALISIS KUALITAS PRODUK, PELAYANAN DAN BRAND IMAGE TERHADAP MINAT KONSUMEN PADA PO. ROSALIA INDAH
}

\author{
Wibi Febrian, Burhanudin Ahmad Yani, Ratna Damayanti \\ Program Studi Manajemen, Fakultas Ekonomi Univesitas Islam Batik Surakarta \\ Email : wibifebrianz@gmail.com
}

\begin{abstract}
This study aims to determine the effect partially and simultaneously product quality, service and brand image on consumer interest in PO. Rosalia Indah. This type of research uses quantitative methods. The population in this study was conducted on 100 respondents spread across the Solo Raya area, namely Solo, Sukoharjo, Karanganyar, Sragen, Wonogiri, Klaten and Boyolali. The sampling technique used in this study was purposive sampling technique. The analytical method used is multiple linear regression, data collection methods by distributing questionnaires. The results of this study indicate a simultaneous and significant effect of product quality, service and brand image on consumer interest in PO. Rosalia Indah with a value of Fcount $\geq$ Ftable $(90.065 \geq 2.70)$ and a significance of $0.000 \leq 0.05$. Partially product quality and brand image have a positive and significant effect on consumer interest with ttable value $\leq$ tcount (1.984 $\leq 4.311)$ on product quality and ttable value $\leq$ tcount $(1.984 \leq 2.576)$ on brand image, while for service variables, ttable value $\leq$ tcount $(1,984 \geq 1,094)$ and a significance value of $0.277 \geq 0.05$ so that the service variable does not have a positive effect on consumer interest in PO. Rosalia Indah.
\end{abstract}

Keywords: Product Quality, Service, Brand Image and Consumer Interest

\begin{abstract}
Abstrak : Penelitian ini bertujuan untuk mengetahui pengaruh secara parsial maupun simultan kualitas produk, pelayanan dan brand image terhadap minat konsumen pada PO. Rosalia Indah. Jenis penelitian ini menggunakan metode kuantitatif. Populasi dalam penelitian ini dilakukan pada 100 responden yang tersebar di area Solo Raya yaitu Solo, Sukoharjo, Karanganyar, Sragen, Wonogiri, Klaten dan Boyolali. Teknik pengambilan sampel yang digunakan pada penelitian ini menggunakan teknik purposive sampling. Metode analisis yang digunakan adalah regresi linier berganda, metode pengumpulan data dengan cara menyebar kuesioner/angket. Hasil penelitian ini menunjukkan pengaruh simultan dan signifikan kualitas produk, pelayanan dan brand image terhadap minat konsumen pada PO. Rosalia Indah dengan nilai $F_{\text {hitung }} \geq F_{\text {tabel }}(90,065 \geq 2,70)$ dan signifikansi 0,000 $\leq 0,05$. Secara parsial kualitas produk dan brand image berpengaruh positif dan signifikan terhadap minat konsumen dengan nilai $t_{\text {tabel }} \leq t_{\text {hitung }}(1,984 \leq 4,311)$ pada kualitas produk dan nilai $t_{\text {tabel }} \leq t_{\text {hitung }}(1,984 \leq 2,576)$ pada brand image, sedangkan pada variabel pelayanan nilai $t_{\text {tabel }} \leq t_{\text {hitung }}(1,984 \geq 1,094)$ dan nilai signifikansi $0,277 \geq 0,05$ sehingga variabel pelayanan tidak berpengaruh secara positif terhadap minat konsumen pada PO. Rosalia Indah.
\end{abstract}

Kata Kunci: Kualitas Produk, Pelayanan, Brand Image dan Minat Konsumen 


\section{PENDAHULUAN}

Era globalisasi saat ini, teknologi komunikasi dan informasi mendorong semakin cepatnya perkembangan peran sektor jasa. Hal ini menjadi dampak perusahaan jasa yang dapat mengalami pertumbuhan dan berkembang menjadi sangat kompleks. Dewasa ini, perkembangan transportasi juga sangat pesat, dengan memberikan fasilitas berbagai bentuk dan jenis alat transportasi bagi kehidupan manusia. Transportasi memiliki peranan penting dalam segala aspek kehidupan, baik dalam aspek sosial, ekonomi, lingkungan, politik, pertahanan, dan keamanan. Transportasi juga merupakan sarana perkembangan yang penting dalam roda perekonomian (Ningsi \& Putriyani, 2019). Meningkatnya kebutuhan masyarakat akan jasa transportasi, berpengaruh juga pada meningkatnya jumlah perusahaan jasa transportasi yang berkompetisi untuk memenuhi kebutuhan tersebut. Setiap perusahaan jasa transportasi menawarkan banyak keunggulan baik dari segi fasilitas, pelayanan maupun harga. Sehingga, memiliki strategi yang tepat dapat membuat setiap perusahaan untuk tetap bertahan, mengalami perkembangan dan mampu memenangkan kompetisi (Ningsi \& Putriyani, 2019).

Kualitas merupakan salah satu syarat untuk menarik dan menumbuhkan minat masyarakat untuk menggunakan jasa maupun produk pada suatu perusahaan. Produk dan jasa dianggap berkualitas jika dapat memenuhi harapan dan kebutuhan masyarakat, terutama pada bidang transportasi (Susanti, 2017).

Setiap produk memiliki merek atau brand yang diciptakan oleh produsen, hal ini bertujuan agar konsumen dapat mengenal produk tersebut. Adanya merek atau brand ini memiliki peranan penting dalam proses pengenalan akan produk terhadap konsumennya. Konsumen akan lebih mengingat sebuah produk yang memiliki keunikan tersendiri, yang berarti merek tersebut berhasil menunjukkan eksistensinya dalam benak konsumen (Rafidah, Kurniawan, \& Zia, 2016).

Menurut Wijayanto \& Suharti (2018) kualitas pelayanan (service quality) adalah salah satu faktor dalam keputusan konsumen dalam membeli. Pengukuran kualitas pelayanan dapat dilakukan dengan membandingkan persepsi antara pelayanan ideal yang diharapkan dengan pelayanan yang diterima oleh konsumen. Jika pelayanan yang diterima konsumen sesuai dengan apa yang diharapkan, dapat diartikan bahwa kualitas pelayanan tersebut baik dan memuaskan. Jika pelayanan yang diterima melampaui harapan konsumen, dapat diartikan kualitas pelayanan tersebut ideal. Namun sebaliknya, ketika pelayanan yang diterima tidak sesuai atau lebih rendah dibandingkan dengan apa yang diharapkan oleh konsumen, maka kualitas pelayanannya dianggap buruk.

Saat ini adanya pandemi Covid-19 yang melanda Indonesia sangat mempengaruhi penyedia jasa transportasi bus terutama pada Agen Bus Rosalia Indah, karena virus sangat mudah menular melalui kontak fisik sehingga pemerintah menghimbau agar masyarakat selalu menjaga jarak atau psyical distancing, pembatasan sosial berskala besar (PSBB), serta adanya larangan mudik.

Kemudian pada Kompas.com edisi 21 April 2020 diketahui bahwa akibat adanya pandemi Covid-19 dan larangan mudik akan mempengaruhi pelayanan sewa armada terutama pada agen PO. Rosalia Indah. PO. Rosalia Indah biasanya setiap tahunnya dapat melayani sewa armada untuk pelayanan mudik, namun pada tahun ini pelayanan tersebut belum ada. Selain itu, biasanya pada saat momen lebaran pemesanan untuk perjalanan wisata juga cukup tinggi, akan tetapi semenjak adanya pandemi ini konsumen banyak yang meminta penjadwalan ulang dan belum ada pemesanan, hal ini menyebabkan pelayanan armada yang dikeluarkan oleh PO. Rosalia Indah hanya sebagian saja (Purnomo, 2020). 


\section{LANDASAN TEORI}

\section{Kualitas Produk}

Kualitas produk adalah sekelompok karakteristik produk yang didapatkan dari pemasaran, rekayasa, produksi dan pemeliharaan, sehingga membuat produk tersebut dapat digunakan untuk memenuhi harapan konsumen. Kualitas merupakan hal yang menjadi pertimbangan konsumen dengan berdasar pada pengalaman konsumen terhadap produk atau jasa. Semakin baik kualitas produk, maka akan berpengaruh pada kepercayaan konsumen pada sebuah merek produk (Wijaya, 2011).

\section{Pelayanan}

Kualitas pelayanan mendorong konsumen dalam menjalin hubungan yang kuat dengan perusahaan. Dalam jangka panjang, hubungan tersebut membuat perusahaan untuk lebih memahami apa harapan dan kebutuhan konsumen. Konsumen akan merasa puas apabila kualitas pelayanan yang diberikan suatu perusahaan baik. Setelah konsumen merasa puas, maka konsumen akan membuat perbandingan dengan pelayanan yang diberikan pada perusahaan lain (Wijaya, 2011).

\section{Brand Image}

Brand image (citra merek) adalah identitas dari barang atau jasa. Sumber asset penting tercipta ketika sebuah merek berkembang dan dapat menunjang kegiatan pemasaran perusahaan (Fure, Lapian, \& Taroreh, 2015). Brand image (citra merek) juga merupakan gambaran dari seluruh persepsi, yang diciptakan dari berbagai informasi dan pengalaman masa lalu terhadap merek tersebut. Citra terhadap merek berhubungan dengan keyakinan dan prioritas konsumen terhadap suatu merek. Citra positif terhadap suatu merek yang dimiliki konsumen, akan memungkinkannya dalam melakukan pembelian (Gadau, 2016).

\section{Minat Konsumen}

Menurut Ningsi \& Putriyani (2019) minat adalah kecenderungan yang dimiliki individu untuk tertarik pada suatu objek. Minat didefinisikan sebagai pendorong individu untuk memberikan perhatian terhadap sesuatu atau orang lain. Sedangkan minat konsumen adalah sikap yang dimiliki konsumen untuk menunjukkan besarnya komitmen dalam melakukan pembelian atau penggunaan produk/jasa. Tumbuhnya minat konsumen disebabkan adanya suatu motif yang sesuai dengan keinginan dan kebutuhan konsumen dalam menggunakan produk/jasa. Minat konsumen juga merupakan hasil dari evaluasi terhadap suatu produk/jasa.

\section{METODE PENELITIAN}

Penelitian ini menggunakan jenis penelitian deskriptif dengan pendekatan kuantitatif. Jenis penelitian ini digunakan untuk menggambarkan fenomena yang terjadi dengan hasil dari data di lapangan yang kemudian dijabarkan dalam bentuk tulisan maupun tabel dan disajikan. Pengumpulan data pada pendekatan kuantitatif menggunakan instrumen penelitian melalui penyebaran kuesioner kepada responden yang berdomisili di Solo Raya dan telah memenuhi syarat tertentu. Teknik purposive sampling digunakan dalam penelitian ini dengan mengambil sampel dari keseluruhan populasi yaitu 100 responden. Metode analisis data yang digunakan dalam penelitian ini adalah analisis regresi linier berganda, uji asumsi klasik, uji F, uji t, dan uji koefisien determinasi $\mathrm{R}^{2}$ yang diolah dengan program SPSS. 


\section{HASIL DAN PEMBAHASAN}

1) Uji Normalitas

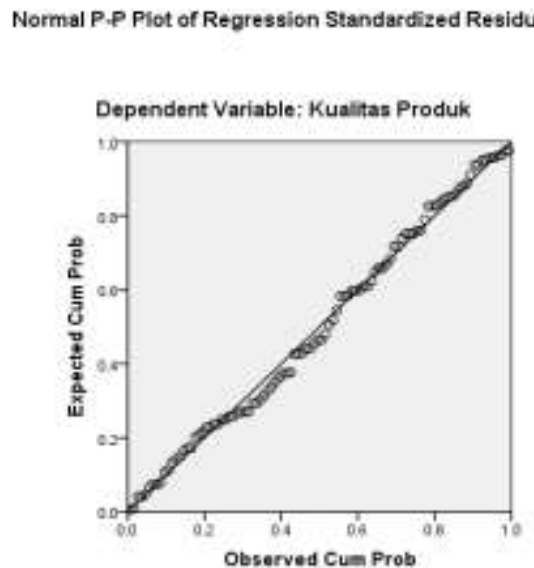

Berdasarkan grafik normal plot tersebut, menunjukkan bahwa model regresi memenuhi asumsi normalitas.

\section{2) Uji Multikolinieritas}

\begin{tabular}{|c|c|c|c|}
\hline Variabel & Tolerence & VIF & Keterangan \\
\hline Kualitas & 0,270 & 3,703 & $\begin{array}{l}\text { Tidak ada } \\
\text { multikoline } \\
\text { aritas }\end{array}$ \\
\hline Pelayanan & 0,184 & 5,433 & $\begin{array}{l}\text { Tidak ada } \\
\text { multikoline } \\
\text { aritas }\end{array}$ \\
\hline $\begin{array}{l}\text { Brand } \\
\text { Image }\end{array}$ & 0,161 & 6,211 & $\begin{array}{l}\text { Tidak ada } \\
\text { multikoline } \\
\text { aritas }\end{array}$ \\
\hline
\end{tabular}

3) Uji Heteroskedastisitas

\begin{tabular}{|c|c|c|}
\hline Variabel & Sig. & Keterangan \\
\hline $\begin{array}{l}\text { Kualitas } \\
\text { Produk }\end{array}$ & 0,000 & $\begin{array}{c}\text { Tidak terjadi } \\
\text { heteroskedastisitas }\end{array}$ \\
\hline Pelayanan & 0,277 & $\begin{array}{c}\text { Tidak terjadi } \\
\text { heteroskedastisitas }\end{array}$ \\
\hline $\begin{array}{l}\text { Brand } \\
\text { Image }\end{array}$ & 0,012 & $\begin{array}{c}\text { Tidak terjadi } \\
\text { heteroskedastisitas }\end{array}$ \\
\hline
\end{tabular}




\section{4) Analisis Regresi Linier Berganda}

\begin{tabular}{|l|c|c|}
\hline \multirow{2}{*}{ Variabel } & \multicolumn{2}{|c|}{$\begin{array}{c}\text { Unstandarized } \\
\text { Coefficient }\end{array}$} \\
\cline { 2 - 3 } & $B$ & Std. Error \\
\hline Constant & 2,860 & 1,549 \\
Kualitas & 0,292 & 0,068 \\
Produk & & \\
Pelayanan & 0,086 & 0,079 \\
Brand Image & 0,183 & 0,071 \\
\hline
\end{tabular}

5) Uji Koefisien determinasi $\left(\mathbf{R}^{2}\right)$

\begin{tabular}{|c|c|c|}
\hline$R$ & $\begin{array}{c}R \\
\text { Square }\end{array}$ & Adjusted $R$ Square \\
\hline 0,859 & 0,738 & 0,730 \\
\hline
\end{tabular}

\section{6) Uji F (Uji Simultan)}

Uji F dugunakan untuk mengetahui spesifikasi pengaruh kualitas produk, pelayanan dan brand image terhadap minat konsumen dari analisis data. Berikut adalah hasil daru uji $\mathrm{F}$ :

\begin{tabular}{|c|c|c|}
\hline Ftabel & Fhitung & Sig. \\
\hline 2,70 & 90,065 & $0,000^{\mathrm{a}}$ \\
\hline
\end{tabular}

\section{7) Uji t (Uji Parsial)}

Uji $t$ berfungsi untuk menentukan dan menguji signifikansi pengaruh variabel kualitas produk, pelayanan dan brand image secara parsial terhadap variabel minat konsumen.

\begin{tabular}{|c|c|c|c|c|}
\hline Variabel & $\mathrm{B}$ & $\mathrm{t}$ & Sig. & Keterangan \\
\hline $\begin{array}{c}\text { Kualitas } \\
\text { Produk }\end{array}$ & 0,292 & 4,311 & 0,000 & $\mathrm{H}_{1}$ diterima \\
$\begin{array}{c}\text { Pelayanan } \\
\text { Brand } \\
\text { Image }\end{array}$ & 0,086 & 1,094 & 0,277 & $\mathrm{H}_{2}$ ditolak \\
\hline
\end{tabular}

\section{PEMBAHASAN}

1) Berdasarkan hasil uji hipotesis secara simultan (uji F) menunjukkan $F_{\text {hitung }}=90,065>$ Ftabel $=2,70$. Artinya hasil tersebut membuktikan bahwa kualitas produk, pelayanan dan brand image berpengaruh positif dan signifikan terhadap minat konsumen pada PO. Rosalia Indah.

2) Berdasarkan hasil uji hipotesis secara parsial dalam uji t pada variabel kualitas produk, diketahui nilai $\mathrm{t}_{\text {tabel }}<\mathrm{t}_{\text {hitung }}(1,984<4,311)$ nilai signifikan $0,000<0,05$ maka $\mathrm{H}_{0}$ ditolak dan $\mathrm{H}_{1}$ diterima. Dapat disimpulkan kualitas produk berpengaruh secara positif dan signifikan terhadap minat konsumen pada PO. Rosalia Indah.

3) Berdasarkan hasil uji hipotesis secara parsial dalam uji t pada variabel pelayanan, diketahui nilai $\mathrm{t}_{\text {tabel }}<\mathrm{t}_{\text {hitung }}(1,984>1,094)$ nilai signifikan $0,277>0,05$ maka $\mathrm{H}_{0}$ diterima dan $\mathrm{H}_{1}$ ditolak. Dapat disimpulkan pelayanan tidak berpengaruh secara positif dan signifikan terhadap minat konsumen pada PO. Rosalia Indah. 
4) Berdasarkan hasil uji hipotesis secara parsial dalam uji t pada variabel brand image, diketahui Nilai $\mathrm{t}_{\text {tabel }}<\mathrm{t}_{\text {hitung }}(1,984<2,576)$ nilai signifikan $0,012<0,05$ maka $\mathrm{H}_{0}$ ditolak dan $\mathrm{H}_{1}$ diterima. Dapat disimpulkan brand image berpengaruh secara positif dan signifikan terhadap minat konsumen pada PO. Rosalia Indah.

5) Hasil perhitungan untuk determinasi $\mathrm{R}^{2}$ yang diperoleh dari nilai Adjusted $R$ Square sebesar 0,730 . Hal tersebut berarti bahwa variabel kualitas produk, pelayanan dan brand image berpengaruh sebesar 73\% terhadap variabel minat konsumen. Sisanya sumbangan variabelvariabel lain hanya sebesar $27 \%$ seperti promosi, harga, kepercayaan merek dan lain-lain.

\section{KESIMPULAN}

Berdasarkan hasil pemaparan penelitian dan pembahasan di atas, maka dapat ditarik kesimpulan bahwa adanya pengaruh simultan dan signifikan kualitas produk, pelayanan dan brand image terhadap minat konsumen pada PO. Rosalia Indah. Kemudian secara parsial variabel kualitas produk dan brand image berpengaruh positif dan signifikan terhadap minat konsumen, namun variabel pelayanan tidak berpengaruh positif dan signifikan terhadap minat konsumen pada PO. Rosalia Indah.

\section{SARAN}

Pada penelitian ini penulis memberikan saran-saran yang bermanfaat antara lain:

1) Secara teoritis

Diharapkan peneliti selanjutnya untuk mengembangkan penelitian ini dengan menggunakan variabel bebas lainnya selain kualitas produk, pelayanan dan brand image yang dapat mempengaruhi minat konsumen, mengingat masih terdapat pengaruh sebesar $27 \%$ di luar variabel penelitian ini seperti promosi, harga, kepercayaan merek dan lain-lain.

2) Secara praktis

a. Sebaiknya PO. Rosalia Indah lebih berinovasi dalam meningkatkan kualitas produk bagi konsumen serta menciptakan keunggulan-keunggulan baru yang tidak disediakan oleh perusahaan otobus lainnya, seperti menyediakan produk shuttle bus dan mengembangkan produk lain yang telah ditawarkan.

b. Diharapkan PO. Rosalia Indah selalu konsisten dalam memberikan pelayanan yang maksimal terhadap konsumen sehingga mampu menimbulkan kenyamanan dan minat konsumen yang lebih dari sebelumnya-sebelumnya.

c. Hendaknya PO. Rosalia Indah selalu memperhatikan brand image dalam rangka meningkatkan minat konsumen. Karena brand image yang baik mampu memberikan persepsi positif masyarakat terhadap suatu produk.

\section{DAFTAR PUSTAKA}

Fure, F., Lapian, J., \& Taroreh, R. (2015). Pengaruh brand image, kualitas produk dan harga terhadap keputusan pembelian konsumen di J.CO Manado. Jurnal EMBA, 3(1), 367-377.

Gadau, M. (2016). Pengaruh citra merek (brand image) terhadap loyalitas konsumen. Skripsi Fakultas Ekonomi Universitas Sanata Dharma Yogyakarta.

Ghozali, I. (2013). Analisis Multivariate dengan Program SPSS Edisi ke-2. Semarang: Universitas Diponegoro. 
Ningsi, B. A., \& Putriyani, A. (2019). Faktor-faktor yang mempengaruhi minat konsumen dalam menggunakan jasa transportasi KRL/commuter line dengan metode analisis faktor. Jurnal Saintika UNPAM, 2(1), 38-50.

Purnomo, A. (2020, April 21). Kompas.Com. Retrieved from Pandemi Corona dan Larangan Mudik Bikin Pengusaha Bus Rugi: https://otomotif.kompas.com/read/2020/04/21/ 162200915/pandemi-corona-dan-larangan-mudik-bikin-pengusaha-bus-rugi

Rafidah, Kurniawan, B., \& Zia, K. (2016). Analisis pengaruh brand awareness dan brand image terhadap keputusan pembelian busana muslim merek rabbani di kota Jambi. Innovatio, 16(2), 75-90.

Sunyoto, D. (2016). Teori, Kuesioner \& Analisis Data untuk Pemasaran dan Perilaku Konsumen. Yogyakarta: Graha Ilmu.

Susanti, D. (2017). Pengaruh kualitas produk terhadap minat konsumen dalam membeli produk tupperware pada perumahan griya tika utama Pekanbaru. Menara Ekonomi, 3(5), 23-32.

Wijaya, E. M. (2011). Pengaruh kualitas pelayanan terhadap loyalitas konsumen, dengan kepuasan konsumen sebagai variabel intervening. Skripsi, 1-39.

Wijayanto, E., \& Suharti. (2018). Pengaruh brand image, attitude, dan service quality terhadap keputusan beli konsumen. Jurnal Manajemen Dewantara, 2(2), 95_104. 